\title{
非水溶液に於けるポーラログラフイー*
}

\section{永田美之 介**}

\section{I. 序}

ポーラログラフィーの砸究に於いて電解腹に は通常水溶液が用いられているが，時としては 水に蜼溶性の物質(主として有機化合物)の晹合 そアルコール類等の有機溶剂の添加に依つてそ の深解度を増大させ满足す心゙き笔解液の調製が 行はれて来た，朔し乍ら多くの有機化合物の川 には有機溶剂号有した水溶液にも難溶液のも のもあり，又有機溶剂の中には水と任意の割合 で混合しないものもあり，之等の障害を避ける ために純非水溶液が電解液として使用される様 になり夫々其の特徵を生かして独特の忍用面が 見出されるに至つている。特に石油工業, 油脂 工業等に相当の応用性があり, 可成の成果が挙 げられている様に思はれる。更に今迄水溶液中 で行はれていた䃑究の中にも，新たにか〉る非 水溶液中で行はれているものも多々あるが，現 在の処非水溶液使用の実閏的な目的は復極剂の 溶解度に関した支障の除去にあると考えられ る。ここでこうした有機溶剂を用いた場合に， 無関係塩として何を用うべきか, 又溶液の $\mathrm{pH}$ を規定するために如何なる緩衝剤を選ぷべきか 等の問題が起つて来る。例へば溶解度の関係か ら無関係告の種類や緩衝䯇の種類には㥵当の制 限があり，又有機溶剂は水溶液の場合に比して 酸素の溶解度方極好て大であり, 従つて溶液中 の溶存酸素の除去には長時間堂要し, 電解液の 抵抗も水溶液より可成大きく従つてポーラログ ラムがねたり，普通の極大抑制剤では抑え難い 極大波を生じたり，長所の反面之等の欠点も指 摘されている。

非水溶液の溶媒は主としてアルコール類，有 機酸, 炭化水素類の如き有機溶剮であるが, 無

* Polarography in Nonaqueous Solution.

** Yoshinosuke Nagata, 京都大学装学部林应化学教 篦
機瀗煤として最近硫酸を使用した破究も二三見 られ，父液体アンモニアや熔融绵中での観祭导 数件見られる。本稿では淮休アンモニヤ川及び

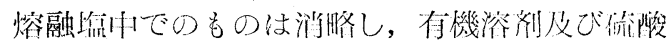
中の侧究を紹介するととにする。

\section{II. 溶媒}

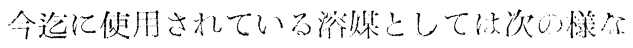
ものがある。

[A]有機溶媒

(1) アルコール類

Primary alcohol (methanol, ethanol butanol, isobutanol, amylalcohol,) ethylene glycol, glycerol

(2) 策化水素類

benzol, ethylene chloride, ethylene bromide

(3) エーテル類

Carbital (diethylene glycol monoethylether) methyl carbital, Cellosolve, methyl cellosolve, dioxane,

(4) 有機酸 glacial acetic acid

(5) 湿合溶桇

benzol-methanol, methanol-dioxane, methanol-glycerol, formamide-acetamide.

(6) 其可他 acetone, formamide, pyridine, tetrahydrofurane, acetonitrile, hydrazine.

[B] 無機溶媒

(1) 硫酸

(2) 液体アンモニア

（3）熔融塩

\section{III. 無関係塩}

通常水溶液の場合に用いられる想関係嫶の队

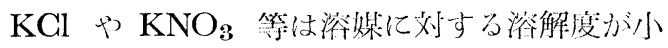

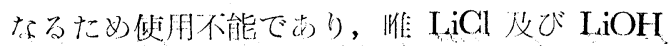




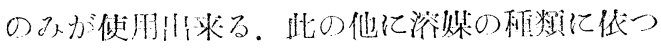
て特杬なるのが田いられている。例へ代承醋酸 の場合に结 $\mathrm{NH}_{4}(\mathrm{AcO})$, methanol-benzol 㺃命に $\mathrm{CH}_{3} \mathrm{HSO}_{4}$ 疗び $\mathrm{LiOCH}_{3}$ がある程度

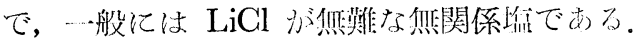

\section{IV. 緩衝剤}

有機化合物の侀究では一般に溶液の $\mathrm{pH}$ を 規定するために，緩衝溶液が用いられている が，非水溶媒飞於いては溶解度の関係汃普通

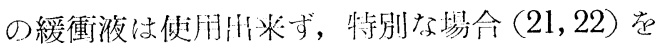

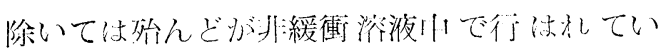
る.

\section{V. 各論}

\section{(A) 有機涳紧}

a) 無機力チォン

崸に水溶液中で立尔研究されたイオンである が，水溶液中では見ら炕ない様な挙動》゙多々見 忧れている。

(i) methanol Hの $\mathrm{Cu}^{++},{ }^{11,33)}, \mathrm{Zr}^{+4},{ }^{5)}$, heavy halide ${ }^{20)}$ methanol $+\infty \mathrm{Cu}^{++}$\& Bonn 学派の極大理論の砸究の一部であつて，2m$\mathrm{LiCl}$ を無関係程とした時， $\mathrm{Cu}$ の䢱元波に続

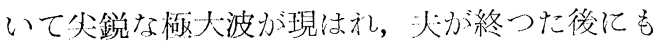
拡散電流まで降下せず第 2 稹の極大波が残り, ずつと陰電位てで消失する。この内第 1 の極大波 统 cetylalcohol $\left(\mathrm{C}_{15} \mathrm{H}_{33} \mathrm{OH}\right)$ 又は eosin 亿依 つて抑制され， eosin の場合は波は well-defined となり定量に利用州来るが，第 2 種の極大は雨 者依つても消失されない。乙の極大は所謂 Spüleffekt に素くもので，滴下時間の速い時に 現はれるから，滴下速度を遅くすることに依つ てこの種の極大を除去することが㽏来る。又第

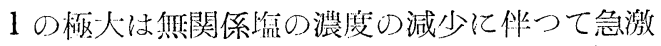
に増大する。極大の性質を見るため，深液中に graphiteの微粉末を晒濁させて滴下極周辺の液 の流動を観祭し，流動のj问文び速度の関係か ら檄大の原因方迫求されている。

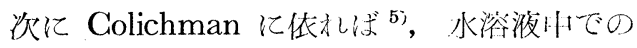

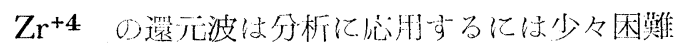

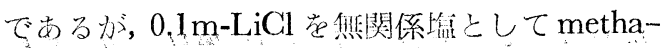

nol 川で行ば， Z $\mathrm{r}^{+4}$ の嫶の林類により一段 又は二段の滥元波が示され，水溶液巾上り良好 である。

义 Riccoboni ${ }^{20)}$ は重全属の halide 虑 methanol 巾で㑣究している。

（ii）承醋酸中の $\mathrm{Cu}^{++}, \mathrm{Zn}^{++3)}$ 及ひび $\mathrm{Cd}^{++}$, $\mathrm{Tl}^{+10)}$

一般に氷醋睃中では水素の析归電位がー $1.2 \mathrm{~V}$ 阶近であるため，それより陽な壮波電位を有す る物箅のみが刘照となることはいふまでもな い.

$\mathrm{Bachman}^{3)}$ \& $0.25 \mathrm{~m}-\mathrm{NH}_{4}(\mathrm{AcO})$ を鮘関係 嫶として電気毛管曲線と極大波の関係を钼祭し た. 毛管旧線は毛管零電位附近に極小を持ち, 之は水添加に從つて漸次消尒して普通の川線に 復元する。毛学䏣線の第 1 の極大より陰の電位 に半波電位を有するカチオン（Class I: $\mathrm{Zn}^{++}$, $\mathrm{Pb}^{++}, \mathrm{Cd}^{++}$, 等) を添加しても毛管曲線は水深 液の埸合の毛管曲線には戻らず，第 1 の極大よ り陽な電位に半波電位を持つカチオン（Class $\mathrm{II}: \mathrm{Cu}^{++}, \mathrm{Fe}^{++}$等) を添加すると, 毛管曲線は 不規則に乱れる。かつるClass II のカチオンを 復極剂とした場合，その僈元波には顕省な極人

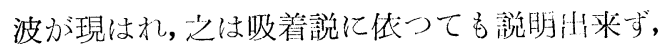
父流動説ではその一部の説明に止るが，Bachmanは毛管曲線の挙動から説明を与へている。

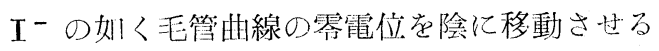
イオンが添加されると, Class I 亿属するもの でClassIに変るカチオンが出て来る( $\mathrm{Bi}^{+++}$等 $)$. 極大抑制剂には gelatin, methyl red 等がある が，その作用は水溶液の時程效果的ではない。 $\mathrm{Hala}^{10)}$ は 0-2n- $\mathrm{LiClO}_{4}$ を無関係塩として $\mathrm{Cd}^{++}$, $\mathrm{Tl}^{+}$を破究し，その暧元波には Ilkovic 式が適 用计来，定量分析に灾用师来る充分心精度を有 している。

(iii) 其の他

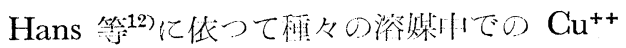
の挙動が砄究されて抏り, 溶媒としては primary alcohol t始》 pyridine, benzol-methanol 等が胕いられ， LiGl が深加されている。何れ

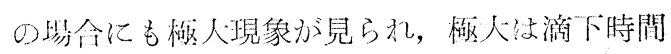
に影響される。父抑制郕は，alcohol 性溶液に 
恃高濃度の抑制剂が必要であり，其の他の溶液 には methyleneblue が最適である。属々の抑

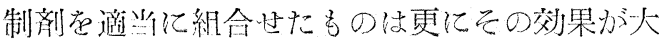
である。

無水ヒドラヂン中でのカテオンの研究量 には 鮥関係塩そ0.1mKCl 又は $\mathrm{HCl}$ を含ませ，照 合電極として $\mathrm{Cd}-\mathrm{CdSO}_{4}$ 電極 $(-0.246 \mathrm{~V}$ 対水 素電極）が使用されている。之封する $\mathrm{Pb}^{++}$, $\mathrm{Cd}^{++}, \mathrm{Zn}^{++}, \mathrm{Ni}^{++}$, 及び $\mathrm{Co}^{++}$の半波電位は夫 々 - $-0.295,-0.050,-0.460,-0.349$ 及び $-0.532 \mathrm{~V}$ であり，還元波は極大を伴い（之は $\mathrm{CeSO}_{4}$ 又は $\mathrm{CaCl}_{2}$ 等の二価カチオンにより 概ね抑制される)，拡散支配である。

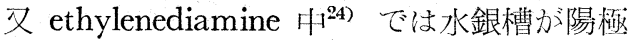
飞用いられ, $\mathrm{Tl}^{+}, \mathrm{Cu}^{++}, \mathrm{Pb}^{++}, \mathrm{Cd}^{++}$の還元 波が観測され，之等は可逆波を示し，その半波 電位は水溶液の場合と異り正の打加 $\mathrm{Tl}^{+}$, $\mathrm{Cu}^{++}, \mathrm{Pb}^{++}, \mathrm{Cd}^{++}$の順になり, 之は溶煤との 鑑塩の安定度に関係している。

非水溶液中での水素過電压の砸究は Vlcek 亿 より acetonitrile ${ }^{31)}$ 及び ethanol ${ }^{32)}$ 中に於いて なされ，溶液に強酸を添加し，前者の場合水素 波は-0.60V (vs, N.C. E.) で析出し，水が添 加されるに従つて急速に陰に移動する。

acetonitrile を使用しての金属カチオンの研 究34) 亿は，無関係塩飞 $\left(\mathrm{C}_{4} \mathrm{H}_{9}\right)_{4} \mathrm{NI}$ 又は $\left(\mathrm{C}_{4}\right.$ $\left.\mathrm{H}_{9}\right)_{4} \mathrm{NClO}_{4}$ が用いられている。乙の時還元 波には大抵の抑制剂で抑えられない極大波が現 はれる、操作の点に於いて，溶媒を空気に触れ させないため常に窒素ガス中で行い.ゴムやグ リースが禁物である等，相当困䧼がある。

(b) 有機化合物

(i) Primary alcohol 中のニトロ化合物 ${ }^{19,21,22)}$

Radin 等19)に依れば, methanol म1 ( $\mathrm{LiCl}$ が 無関係塩）での脂肪族ニト口化合物は比較的傾 斜の緩い一般の還元波を示し，㕍々極大波か現 はれる。乙の極大は methyleneblue, cellosolve に依つては抑制されない. $0.2 \sim 2 \times 10^{-3} \mathrm{~m}$ つ莀 度範囲で拡散電流と瀑度の間に比例性がある。 尚非水溶液ではその粘性係数（ク）が從つて拡

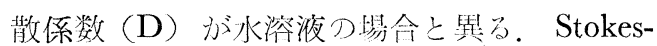
Einstein の式より

$$
\mathrm{D}=\frac{\mathrm{l}}{6 \pi \eta \mathrm{r}} \mathrm{T} \mathrm{T}
$$

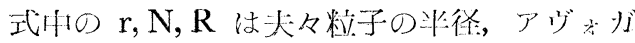
ドロ数，ガス恒数である。從つて Ilkovic 式你

$$
\begin{aligned}
& \mathrm{i}_{d}=\mathrm{kD}^{\mathrm{I} / 2} \mathrm{Cm}^{2 / 3} \mathrm{t}^{1 / 6}=\mathrm{kCm}^{2 / 3} \mathrm{t}^{1 / 6} \sqrt{\frac{1}{6 \pi \eta \mathrm{r}} \mathrm{TR}} \\
& =\mathrm{KCm}^{2 / 3} \mathrm{t}^{1 / 6} \sqrt{\frac{1}{\eta}}
\end{aligned}
$$

となり，拡散電流蛙数性係数の平方根に道比 例する。

Nitroaniline, Nitroacetanilide $\sigma$ 研究 $^{21.22)}$ に 於いては，溶液の $\mathrm{pH}$ を規定するために，特姝 な緩衝系を用いている。即ち用いた陖又は嫶其 のイオン強度を 0.05 とし，その版の pk の倠は 次の圳くである。

perchloric acid 1

o-bromoaniline hydrochloride 3

p-naphthylamine hydrochloride 5

chloroacetic acid 6

m-bromobenzoic acid 8

bezoic acid 9

o-chlorobenzylamine hydrochloride 10

ethylenebarbituric acid $\quad 12$

guanidine hydrochloride $\quad 13$

lithium ethoxide

nitroaniline の o-, m-, p- 買幽体の米波泊位。 の差異を I, T 效果より説明し, ethanol 1で の拡散係数及び還元に与る電子数を求めてい る。

(ii) methanol-benzol 中の peroxide $^{17}$

一般に benzol 依つて復極剂を抽出しても, benzol 丈では満足子電解液飞する事が胡来ない が，之に当量の methanol を添加すればよい。 無関係告には $0.2 \mathrm{mCH}_{3} \mathrm{HSO}_{4}, 0.3 \mathrm{mLiCl}$, 又は $0.1 \mathrm{~m} \mathrm{LiOCH}_{3}$ が採用され，乙の時電解液の抵 抗は約 $4 \mathrm{~K} \Omega$ である. fat peroxide には $\mathrm{LiCl}$, $\mathrm{LiOCH}_{3}$ を用い，三段の還元波が得られるが， 第 3 波の波高と peroxide 数 (Wheeler 法によ り測定)の閒に比例性がある（唯し peroxide 数275以下). ether peroxide に刘しても LiCl, $\mathrm{LiOCH}_{3}$ 将有效である。一j benzoyl peroxide はアルカリに依つて分解される泍ら $\mathrm{LiOCH}$ 


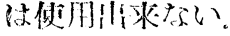

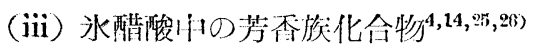

Bergman $^{4)}$ \& $1 \mathrm{~m}-\mathrm{NH}_{4}(\mathrm{AcO})$ 存奥関係嫶亡 して, ニトロ化合物を中心として㮩々の芳否族 化合物の半波電位を皮醋酸中で測定し，nitro一

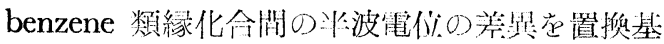
の影響から垷明している。

义…色, 多田等 ${ }^{14,25.26)}$ は Anthraquinone(I), 1,2-benzanthraquinone ${ }^{9,10)}$ (II), 及び 1,2,5,6dibenzanthraquinone ${ }^{9,10)}$ (III) te $\mathrm{NH}_{4}(\mathrm{AcO})$

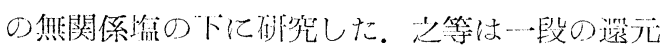
波を示し， iR 補正:をした絬果，（I），（II）,

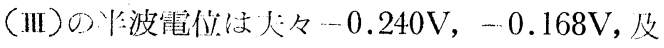
び-0.137V (vs.S. C. E.) であり, $\log$ plot 加ら之等の波は可逆 2 電子僈元であることか洒 められた。

(iv) glycol-ether 110 naphthalene 類 ${ }^{18)}$

Park 等に低れしば, naphthalene, $\alpha$-methylnaphthalene, $\beta$-methyl-naphthalene is Cellosolve, methyl cellosolve 等 $の$ glycol-ether 它量可能である。父 gasoline 1 の tetraethyl

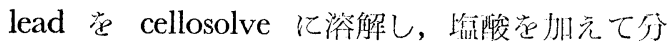
解与れば， $\mathrm{Pb}^{++}$の還元波小゙得られ，之汃ら

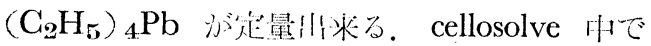
$\mathrm{Pb}^{++}$が份在すると㮽大波か現はれ， methylred に依つて抑制されている。父 cellosolve 中で緩 衝系として acetic anhydride-Na-acetate 及び $\mathrm{NH}_{3}-\left(\mathrm{C}_{2} \mathrm{H}_{5}\right)_{4} \mathrm{NBr}$ 少用いられた。

(V) 其の他

Arther 等》蛙 acetone 中で acid halide $の$ 還元波を得ている。此の時外部陽栖の液絡江法 普通の形の cell では電解液中に水の人る恐れ

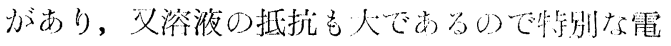
解瓶が考案されてい\%。

formamide 义は formamide-acetamide 学浴 媒とし， $\mathrm{KCl}, \mathrm{KNO}_{3}$ を無関係嫶とした特16,13) benzophenone 等の有機化合物及び $\mathrm{Pb}^{++}$等の 眫機カチオンは還元波を示し, formamide に 対する acetamide の割合によつて深腹の粘性 係数が変化するが，その変化に伴ふ拡散電流の

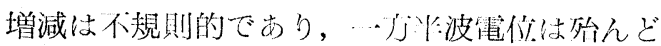
影響されなない,

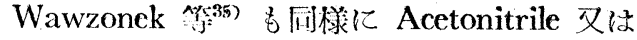
Dimethylformamide 巾で Stilkene, Anthracene, Styrene 等の这元波虚得, 之点利用して電

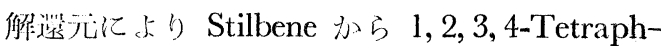
enylbutane 及び meso-Diphenylsuccinic acid を得ている。

Edsberg等 飞依れ将, N, N'-dimethylformamide 在浴䌝として anthracene, phenanthrene, carbazol, phthalic anhydride, 及び maleic

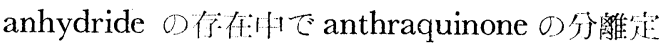
最が可能である。乙の時鲴関係程として $0.1 \mathrm{~m}$ LiCl, anhydride の加水分解用飞 LiOH を添 加して行つている. anthraquinone は二段の 還元波( $-0.83 \mathrm{~V}$ 及び-1.17V vs. S. G.E.) を 示し, 天々の波は $\log$ plotより 1 電子叮逆遙 元であり中間に semiquinone の生成が考尜ら れている。

復極剂の濃度の低い㭙に洁当然波湻も小さく

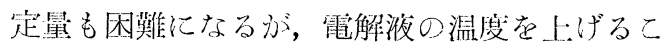
とに低つて波高高くすることが出来る。㗍し 普通の有機溶媒では, 温度か $50^{\circ} \mathrm{C}$ 以上になると 揮発のために容量の変化を来すものが多いが, glycerol はその沸点が㤯く，上の欠点纺十分補 はれている。 De Vries等6) は代れば, benzaldehyde, fumaric acid, p-nitrobenzoic acid, m-nitrobenzoic acid として，100〜140 $\mathrm{C} て ゙$ well-defined な造元波 を示している。文特殊なものとして Pyridine 中で Organochlorosilane の還元波军得て, 之 を利胕してシリコン樹脂㠶 Chlorosilane ぶ 定最されている1)

(B) 無機沙媒

(a) 硫侄运, 27, 28,29,30)

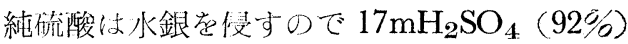
汃用いら虬，㵋媒自体強電解質であるから無関 係嫶は别に淥加されててない，外部電極に硫 酸水銀電植が使用されている。 blank test に於 いて，一0.45V に小さい還元が見られるが， 之は $\mathrm{H}_{2} \mathrm{SO}_{4}$ 中下合京れる iSulphurous oxide $\mathrm{SO}\left(5 \times 10^{-5} \mathrm{~m}\right)$ の還元波であり， SO は

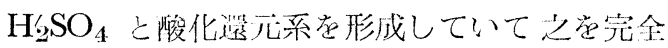

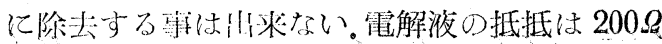


以下で，水素の析電位は一 $-0.8 \mathrm{~V}$ である。電 父毛管曲線は泟掌な形状を示している。 $\mathrm{H}_{2} \mathrm{SO}_{4}$ は強力な脱水作胉芭有し, 特殊な極性が沘り, そ等の性質が $\mathrm{H}_{2} \mathrm{SO}_{4}$ の濃度によつて異り，そ のため復撙剂の半波雪位が $\mathrm{H}_{2} \mathrm{SO}_{4}$ の浱度の变 化によつて影響を受けっ。例へ代，濃度の增大 に伴ふ $\mathrm{Cd}^{++}, \mathrm{Tl}^{+27,28)}$ の半波電位の陰又は陽へ の移動㳉，水和イオン， $\mathrm{H}_{2} \mathrm{SO}_{4}$ との錯化合物， 水等つ活量の変化汃ら現象が説明されている。 即占半波電位注次式で玟現される。

$$
\mathrm{E} 1 / 2=\frac{\mathrm{RT}}{\mathrm{nF}} \operatorname{lnk} \cdot \mathrm{K}_{s}-\mathrm{x} \frac{\mathrm{R}^{\top} \mathrm{T}}{\mathrm{nF}} \ln \mathrm{C}_{s}-\mathrm{x}^{\mathrm{RT}} \mathrm{nF}_{\mathrm{nf}} \ln
$$

$\mathrm{k}, \mathrm{K}_{s}, \mathrm{C}_{s}, \mathrm{f}_{s}$ ，及び $\mathrm{x}$ は夫々金属カチオン種 飞特有の常数，錯化恒数、錯化合物を作る物質 の浱度，その活量係数，及び金属カチオンと絬 合する錯化剂の分子数を表はしている。半波電 位の陽、の移動は，錯化合物からイオンに解離 することによる活量の増大を意味し，逆に陰電 位への移動活活量の減少と鍇化合物の形成及び 资定化を意昧している。 fs は $\mathrm{H}_{2} \mathrm{SO}_{4}$ 濃度の 狄い範田でる一定と見做される仯。

$$
\frac{\mathrm{dE} 1_{2}}{\mathrm{dln}_{s}}=-\mathrm{x} \frac{\mathrm{R} \mathrm{T}}{\mathrm{nF}}
$$

$\mathrm{E} 1 / 2$ の $\log \mathrm{C}_{s}$ に対するplot の傾斜少ら $\mathrm{x}$ が

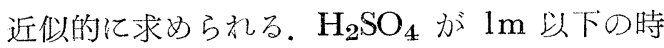
には, $\mathrm{Cd}^{++}$の半波電位は $\mathrm{Tl}^{+}$の夫と異つた 特異的子変移在するが， $10 \mathrm{~m}$ 以上では雨者共 陰龟位に移動し，之はイオンの活量の減少から 镜明され，その減少は新しい鍇化会物，即占 $\mathrm{H}_{2} \mathrm{SO}_{4}$ と solvation complex の形成に基くも

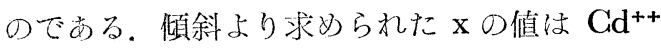
及び $\mathrm{Tl}^{+}$につき夫々 10 及び 23 であり，乙の值 は solvation 数に比例し, $\mathrm{Tl}^{+}$は $\mathrm{H}_{2} \mathrm{SO}_{4}$ 中で は $\mathrm{Cd}^{++} よ り 23 \%$ 倍強く solvate しているて とを走している。

又同しく Vlcek ${ }^{29)}$ により $\mathrm{SO}_{2}$ 及び $\mathrm{Br}_{2}$ が
$\mathrm{H}_{2} \mathrm{SO}_{4}$ 中で研究された。 夫々の半波電位は一

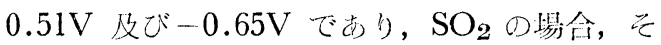
の浱度 $(\mathrm{C})$ ）限界雪流（i $\mathrm{i}_{l}$ ）の関係は直線で なく $\left(\mathrm{i}_{l}=\mathrm{k} \mathrm{C}^{x}, \mathrm{x}>1\right), \quad \mathrm{i}_{l} \quad \measuredangle \sqrt{\mathrm{h}}(\mathrm{h}$ は水銀溜 の高さ)は一次関係にあるが, 兑の直線は電流軸 足正の值で切り, その点の電流值 $\mathrm{i}_{k}$ は $\mathrm{i}_{k}=\mathrm{k}^{\prime} \mathrm{C}^{x}$

$(\mathrm{x}>1)$ なる関係他あり，( $\left.\mathrm{i}_{l}-\mathrm{i}_{k}\right)$ は $\mathrm{G}$ 亿比例 している。従つて $\mathrm{SO}_{2}$ の限界電流は必忘電流 の性質を有し，之は還元された $\mathrm{SO}_{2}$ の生成物 か禰極界面で， $\mathrm{H}_{2} \mathrm{SO}_{4}$ により速やかに陖化さ れて $\mathrm{SO}_{2}$ が再製され，その $\mathrm{SO}_{2}$ が再び電極 で還元されることに基いている，又 $\mathrm{i}_{l}$ は $\left(\mathrm{t}^{1 / \mathrm{s}}\right.$ $\left.+\mathrm{t}^{2 / 3}\right)$ ( $\mathrm{t}$ は滴下時間) 飞比例している。 $\mathrm{Br}_{2}$ 亿 ついても同柡な挙動が見られるぶ $\mathrm{i}_{l}$ は $\left(\mathrm{t}^{1 / 6}+\right.$ $\left.\mathrm{t}^{5 / 3}\right)$ に比例している。等の㬰験式は不十分乍 ら理論的に説明されている。

次に nitrobenzene を主体とするニトロ化合 物 ${ }^{15)} \mathrm{H}_{2} \mathrm{SO}_{4}$ 中で一段波を示し，その半波電

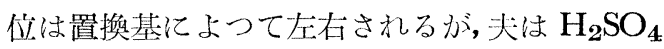
中で顕著にイオン化される様な置換 nitrobenzene の時にのみ見られる。文道元機構につい ては Peasson 等の水溶液中の場合と同様である と考えている.

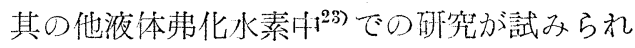
ているが装置の試作程度であつて, 取扱上非常 に困败である。

(b) 液体アンモニア及び熔融塩

そについては文の機会に瀼り，文献のみを後 に話して打く。

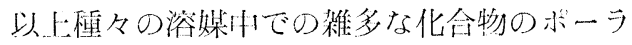
ログランィーについて交献を紹介してみたが， 余りにも秩序がないので一表にしてみると次 の様になつた。尚抜けている文献があると思は れるが﨏指摘下されば宰罢に思います。

\begin{tabular}{l|l|l|c}
\hline \multicolumn{1}{c|}{ Solvent } & \multicolumn{1}{|c|}{ Depolarizer } & Indifferent Electrolyte & Ref. \\
\hline \multirow{2}{*}{ Methanol } & Havymetallic halide & $\mathrm{LiCl}$ & 20 \\
& $\mathrm{Zr}+4$ & $\mathrm{LiCl}$ & 5 \\
& $\mathrm{Cu}++$ & $\mathrm{LiCl}$ & $11,12,33$ \\
& Nitro-compounds & $\mathrm{LiCl}$ & 19 \\
Ethanol & Nitroailine, etc. & Buffer & 21,22
\end{tabular}




\begin{tabular}{|c|c|c|c|}
\hline & Hydrogen overvoltage & strong acid & 32 \\
\hline Glycerol & Benzaldehyde, etc. & & 6 \\
\hline Ethylene-glycol & $\mathrm{Cd}^{++}, \mathrm{Zn}^{++}$, etc. & LiGl & 9 \\
\hline Methanol-benzene & Peroxide & $\mathrm{LiCl}, \mathrm{LiOCH}_{3}$ & 17 \\
\hline \multirow[t]{4}{*}{ Acetic acid } & Aromatic-compounds & $\mathrm{NH}_{4}(\mathrm{AcO})$ & 4 \\
\hline & $\mathrm{Cu}^{++}, \mathrm{Zn}^{++}$ & $\mathrm{NH}_{4}(\mathrm{AcO})$ & 3 \\
\hline & $\mathrm{Cd}^{++}, \mathrm{Tl}^{+}$ & $\mathrm{LiClO}_{4}$ & 10 \\
\hline & Anthraquinone, etc. & $\mathrm{NH}_{4}$ (AcO) & $14,25,26$ \\
\hline Cellosolve, etc. & Naphthalene, etc. & $\left(\mathrm{C}_{4} \mathrm{H}_{9}\right)_{4} \mathrm{NI}$ & 18 \\
\hline Acetone & Acid halide & $\mathrm{LiCl}$ & 2 \\
\hline Formamide-acetamide, & Benzophenone, etc. & $\mathrm{KGl}, \mathrm{KNO}_{\sharp}$ & 13,16 \\
\hline \multirow[t]{2}{*}{ Acetonitrile } & Metallic ions & $\left(\mathrm{C}_{4} \mathrm{H}_{9}\right)_{4} \mathrm{NI}$, etc. & 34 \\
\hline & Hydrogen overvoltage & strong acid & 31 \\
\hline Hydrazine & $\mathrm{Pb}^{++}, \mathrm{Cd}^{++}$, etc. & $\mathrm{KCl}, \mathrm{HCl}$ & 8 \\
\hline Ethylenediamine & $\mathrm{Tl}^{+}, \mathrm{Cu}^{++}$, etc. & & 24 \\
\hline $\mathrm{N}, \mathrm{N}^{\prime}$-dimethylformamide, & Anthraquinone & $\mathrm{LiGl}$ & 7,25 \\
\hline Pyridine & Orgamochlorosilane & $\mathrm{LiCl}$ & 1 \\
\hline
\end{tabular}

\section{文献}

1) Abrahamson, E. A.Jr., and Reynolds, C. A. : Anal. Chem., 24, 1827 (1952)

2) Arther, P., and Lyons, H.: Anal. Chem, 24, 1422 (1952)

3) Bachman, G.B., and Astle, M.J. : J.A.G.S., 64, 1303, 2177 (1942)

4) Bergman, I. and James, J.G.: Trans. Faraday Soc., 48, 956 (1952)

5) Colichman, E.L. and Ludewig, W.H.: Anal. Chem., 25, 1909 (1953)

6) De Vries, T. and Bruss, D.B.: J. Electrochem. Soc., 100, 445 (1953)

7) Edsberg, R.L., Eichlin, D., and Garis, J. J.: Anal. Chem., 25, 798 (1953)

8) Furlani, G. : Ann. chim., 45, 264 (1955)

9) Gentry, C.H.R. : Nature, 157, 479 (1946)

10) Hala, E.: Chem. Obzor., 23, 145 (1948) C.A., 43, 2879 (1949)

11) Hans, W. and von Strum, F.: Z. Elektrochem., 57, 416 (1953)

12) Hans,W. and von Strum, F. : Angew. Chem., 65, 393 (1953)

13) Hook, J.H., Letaw, H.Jr., and Gropp, A.H. : J. phys. Chem., 58, 81 (1954)

14) Isshiki, T. and Tada, K.: Pharm. Bull. Japan, 2, 266 (1954)

15) James, J.G. : Trans. Faraday Soc, 47, 1240
(1951)

16) Letaw, H.Jr., and Gropp, A.H. : J.Phys. Chem., 57, 964 (1953)

17) Lewis, W.R., Quackenbush, F. W., and De Vries, T.: Anal. Chem., 21, 762 (1949)

18) Parks, T.D., and Hansen, K.A : Anal. Chem., 22, 1268 (1950)

19) Radin, N. and De Vries, T.: Anal. Ghem., 24, 971 (1952)

20) Riccoboni, L. and Popoff, P. : Gazz. chim. ital., 79, 573 (1949); G.A., 44, 1831 (1950)

21) Runner, M.E. and Wagner, E.C.: J.A.C.S., 74, 2529 (1952)

22) Runner, M.E.: J.A.C.S., 74, 3567 (1952)

23) Sargent, J.W., Glifford, A. F., and Lemmon, W.R. : Anal. Chem., 25, 1727 (1955)

24) Schaap, W.B., Messner, A.E., and Schmidt, F. C. : J.A.G.S., 77, 2683 (1955)

25) Tada, K.: Pharm. Bull. Japan, 2, 270 (1954)

26) Tada, K.: Pharm. Bull. Japan, 2, 272 (1954)

27) Vlcek, A.A.: Collection, 16-17, 230 (1951-52)

28) Vlcek, A.A.: Pr.c. I. Inter. Polaro. 'Congr. in Prague, III , 373 (1952)

29) Vlcek, A. A.: Collection, 16-17, 465 (1951-52)

30) Vlcek, A.A.: Chem. Listy, 47, 1162 (1953)

31) Vlcek, A.A.: Chem. Listy, 48, 1741 1954: C.A, 49, 5158 (1955), Collection, 20, 636 (1855)

32) Vlcek, A.A.: Chem. Listy, 49, 28 (1955) : C.A., 49, 5158 (1955), Collection, 20, 889 (1955) 
33) Wahlin, E. and Hans, W.: Z. Ellektrochen.., 56, 130 (1952)

34) Wawzonek, S. and Runner, M.E.: J. Electrochem. Soc., 99, 457 (1952)

35) Wawzonek, S., Blaha, E.W., Berkey, R. and Runner, M. E. : J. Electroohem. Soc., 102, 235 (1955)

液体アンモニア

Laitinen, H.A., et al.: Polarography in liquid ammonia.

I. The alkali metals. J.A.C.S., 70, 2241 (1948)

II. The electron electrode. ibid., 70, 3002 (1948)

15. The mercury poolanode. ibid., 72, 663 (1950)

IV. The polarography of thallium ( I ), copper (II), and ammonium ions and of molecular oxygen. ibid., 72, 4975 (1950)

$\mathrm{V}$. The polarography of $\mathrm{Pb}, \mathrm{Cd}, \mathrm{Zn}, \mathrm{Ni}, \mathrm{Co}, \mathrm{Cr}$, and $\mathrm{Al}$ ions. J. phys. Chem., 57, 564 (1953) Nyman, G.J. : Polarography of calcium, strontium and barium in liquid ammonia. J.A.G.S., 71, 3914 ( 1949)

Vecchi, E. : Polarographic studies on solution in anhydrons ammonia at roomtemperature and normal pressure. (Italian) Rend. Accad. nazl. Lincei, Classe Sci. fis. mot. nat. (III) 14, 290 (1953)

\section{熔融塩}

Nachtrieb, N.H. and Steinberg, M. : Characteristics of the dropping mecrury electrodein fused salts. J. A. C. S., 70, 2613 (1948)

Chovnyk N.G. : Polarograms of anodic oxidation of stannous ions in melts. Doklady Akad. Nauk SSSR 87, 1033 (1953)
Markov, B. F., and Berenblyum, L. S.: Determination of diffusion coefficients of irons in molten salts. Zhur. fiz. Khim., 27, 1848 (1953)

Delimarskiy, Yu.K. and Panchenko, I.D. : Polarographic investigation of melted salts on the basis of melted potassium nitrate. Ukrain. Khim. Zhur., 19, 46(1953)

Delimarskiy, Yu.K. and Panchenko, I.D. : The application of the Heyrovsky-Ilkovic equation to the polarographic wave obtained with solid electrodes in melted salts. Doklady Akad. Nauk SSSR, 91, 115 (1953)

Lyalikov, Yu.S. : Polarography of fused salts. Zhur. anal. Khim., 8, 38 (1953)

Chovnyk, N. G.: Derived polarograms in molten electrolytes. Doklady Akad. Nauk SSSR, 95, 559(1954) Delimarskiy, Yu. K. : Polarogrcphy of fused salts. Uspekhi Khim., 23,766 (1954)

Delimarskiny, Yu. K.; The electrode potentials of metals in molten salts. Zhur. fiz. Khim., 29, 28 (1955)

Black, E. D. and De Vries, T.; Polarograohy with Platinum microelectrode in Fused salt. Anal. chem., 27, 906 (1955)

Chovnyk, N, G. ; Polarographic investigation of some fused systems of the kaimite type. Sbornik Statei Obshchei Chim., Akad. Nauk S. S. S. R., 1, 179 (1953)

Lyalikov, Yu. S.; Polarographic determination of silver in Fusions with the aid of a platinum electrode. Zhur. Anal. Khim. , 5, 323 (1950) 